\title{
Determining Factors for Cyberbullying Prevention Programmes
}

\author{
Cristina Hennig Manzuoli ${ }^{1} \&$ Liliana Cuesta Medina ${ }^{2}$ \\ ${ }^{1}$ Centro de Tecnologías para la Academia, Universidad de La Sabana, Chía, Colombia \\ ${ }^{2}$ Department of Foreign Languages and Cultures, Universidad de La Sabana, Chía, Colombia \\ Correspondence: Cristina Hennig Manzuoli, Centro de Tecnologías para la Academia, Chía, Colombia, Campus \\ Universitario del Puente del Común, Km. 7, Autopista Norte de Bogotá, Chía, Cundinamarca, Colombia. Tel: \\ 57-1-861-5555. Ext. 42207. E-mail: cristina.hennig2@unisabana.edu.co
}

Received: June 22, 2017

doi:10.5539/ies.v10n12p52
Accepted: August 3, $2017 \quad$ Online Published: November 28, 2017

URL: https://doi.org/10.5539/ies.v10n12p52

\begin{abstract}
This study reports on the first stages of a larger project to develop an ICT-supported cyberbullying prevention programme that fosters development of children's communication skills for the safe use of social media. To establish baseline data on the incidence and growth of cyberbullying in Bogotá, Colombia, we applied a Revised School Violence Questionnaire (CUVE-R) to a population of 1355 fifth-grade pre-adolescents. The results show that cyberbullying is at an early stage in the surveyed educational institutions, and we make specific recommendations on developing cyberbullying prevention programmes that foster effective communication and self-regulatory skills supported by multimodal strategies and ICT tools.
\end{abstract}

Keywords: cyberbullying, pre-adolescents, prevention, programmes, social media

\section{Introduction}

\subsection{Introduction to the Study}

Cyberbullying is considered a form of violence. Although cyberbullying has many of the same characteristics as other forms of school bullying, it also displays new features, such as anonymity, the possibility of gaining greater audiences online, and access to online personal information, which can be modified or altered for different objectives (Fernández \& Cuadrado, 2014; Slonje, Smith, \& Frisén, 2013). Cyberbullying is nowadays recognized as a serious public health problem that affects the lives of many children and adolescents (Aboujaoude, Savage, Starcevic, \& Salame, 2015). Several studies have examined the negative influences of cyberbullying, such as the humiliation and persecution of teenagers who spend time on social media (Strom \& Strom, 2005; Tokunaga, 2010). In fact, the Internet and, especially, social networking sites such as Facebook offer adolescent users a perfect platform for negative comparison (i.e. the experience of negative feelings derived from social comparison) (Frison \& Eggermont, 2016), and adolescents do not always know how to handle these kinds of peer and media pressure. According to Bazelon (2013) and Spies Shapiro and Margolin (2014), the viciousness of cyberbullying is exacerbated by the depersonalized nature of the interactions (postings), as well as the widespread use of social media by teenagers. Pre-adolescents who find themselves in cyberbullying situations do not necessarily have the tools needed to face this type of violence or to develop assertive communication mechanisms that could help regulate their emotions, express their ideas in an effective manner, and act appropriately for the context in which they find themselves. Moreover, adolescence is a stage in which individuals struggle to develop their self-concepts, and many younger adolescents are more likely to present an inconsistent self when they are exposed to online environments (Fullwood, James, \& Chen-Wilson, 2016). Therefore, educational institutions, school committees and other involved educational agents (including parents, teachers, stakeholders, counselors, social workers, nurses, IT, transportation, maintenance and administrative staff) need to be well aware of their students' needs, raising awareness about the safe use of social media and proposing mediation and intervention strategies for this at-risk population.

Cyberbullying, as a phenomenon, has been analysed from different perspectives, though in terms of studies on pre-adolescents (9- to 11-year-olds), there is still much to be researched (Monks, Robinson, \& Worlidge, 2012). Several authors for example (Migliaccio \& Raskauskas, 2013; von Marees \& Petermann, 2012) suggest prevention programmes could be made more effective by studying the internal dynamics of groups of teenagers. Similarly, Swearer et al. (2010) suggest taking an ecological perspective on relationships between the social 
context and its influence on children's behaviour and development, including such aspects as the role of the family, the relationship between parents and their children, students' peers, the school environment, and the relationship between students and teachers. A more detailed analysis of such aspects could help identify students who find themselves involved in school violence. These ideas align with those of Palladino, Nocentino, and Menesini (2012), who found that teenage students who were familiar with a school bullying prevention programme improved their adaptation strategies for conflict resolution and decreased their use of negative coping strategies, such as avoidance, which contributes to decreasing the probability of becoming a victim of bullying or cyberbullying. Such interventions aimed at preventing bullying are necessary given that students who have been school bullies can develop further antisocial behaviours in the future, especially if the bullying was physical (Bender \& Lösel, 2011).

These findings are also validated by Garaigordobil (2017), who found that students with difficulties in handling conflict resolution assertively can develop antisocial behavior. Two major recommendations are emphasized in her study. Firstly, there is a need to foster programs that help pre-adolescents develop and assess their capacities to resolve interpersonal conflicts constructively and to reduce aggressive behavioral tendencies when confronted with conflicts. Secondly, it is important to analyze the consequences of antisocial behavior related to either bullying or cyberbullying or actors involved in these (victims, bullies, and/or bystanders). On the other hand, the examination of potential risk factors associated to phenomena such as bullying and other forms of violence (such as of dating violence perpetration) is necessary (Foshee et al., 2014). Some of these potential risk factors include lack of empathy, trait anger, and need for power and control; deficits in emotion regulation and executive functioning that hinder the development of effective conflict resolution and anger management skills; substance use; normative beliefs that are accepting of aggression; and exposure to family violence. The analysis of associations between these variables and aggressive behavior through appropriate analytical techniques could be beneficial to guide the development of prevention programs towards bullying and dating violence perpetration, for example (Foshee et al., 2014), as the abovementioned risk factors may increase the likelihood that youth who bully will become abusive to dating partners (Connolly, Pepler, Craig, \& Taradash, 2000).

In a recent study, Hennig, Cuesta Medina, and Malfasi (2017) performed a systematic review of studies on bullying and cyberbullying in the ScienceDirect database (http://www.sciencedirect.com/) published between 2010 and 2015. These results draw attention to three fundamental areas of research focus: the existence of bullying and cyberbullying as a latent problem in schools, the prevalence and causes of school bullying, and the psychological and physical consequences for victims of bullying. This same review also found that some reassessment of studies on intervention programmes to prevent school bullying may be warranted, given that such studies generally tend to report positive results in terms of decreasing school bullying behavior (Evans, Fraser, \& Cotter, 2014). Hennig, Cuesta Medina, and Malfasi (2017) also suggest that cyberbullying prevention programs should be nurtured in pre-adolescence (8-11 years) given that, at these ages (as reported in the literature), spend more time using the Internet (Fernández \& Cuadrado, 2014), and need to be trained in the efficient use of information, communication, and socialization resources. Additionally, the authors observe that it is within this age range that pre-teens are in search of their identities and when socialization peer preferences powerfully shape the development of their social skills (Zimmer-Gembeck, Waters, \& Kindermann, 2010).

The lack of cyberbullying studies conducted locally in public and private schools in Bogotá, as well as the systematic review performed by Hennig, Cuesta-Medina, and Malfasi (2017), demonstrate the need for further in-depth research on this topic. Similarly, Rincón and Ávila (2014) and Cabra and Marciales (2015) have noted the dearth of published articles on the issue of cyberbullying in Colombia and Latin America. This must be a priority concern for educators and administrators, as well as researchers. Particularly, it is necessary to diagnose the state of cyberbullying in social media and other online environments with the goal of establishing a baseline to develop prevention programmes that integrate ICTs and the development of communication skills in pre-adolescents, age during which their online interaction and use of social media is beginning (or at least increasing) based on the findings of the present study. Moreover, the population involved in cyberbullying must be clearly defined if an effective prevention programme that integrates ICTs and the development of communication skills is to be developed and, subsequently, evaluated in terms of its effects on the safe use of social media and the development of assertive communication skills.

An interdisciplinary process within school communities must be created to establish strategies and prevention plans at the elementary, secondary, and tertiary levels to reduce the incidence of cyberbullying, and to gauge plans that can overall prevent health, and affective problems nurtured through the incautious use of social networking sites (SNS). Previous studies (Sampasa-Kanyinga, Roumeliotis, Farrow, \& Shi, 2014) have investigated the relation between excessive and/or uncontrolled use of SNS and unmet needs for mental health 
support and/or poor self-rated mental health. Other studies have found that youngsters who experience cyberbullying problems also have difficulties sleeping, recurrent abdominal pain, and frequent headaches (Sourander et al., 2010); they might also present greater symptoms of anxiety, depression, and suicidal ideation in comparison with non-victimized peers (Hinduja \& Patchin, 2010; Kowalski \& Limber, 2013; Schneider, O'Donnell, Stueve, \& Coulter, 2012).

Studies such as those of Ttofi and Farrington (2012) identified high-quality friendships as a protective factor that significantly moderates the relationship between bullying behavior and externalizing problems. However, further research on the matter is warranted. The authors argue that it is possible that good reasoning and problem-solving skills may also reduce the likelihood of school bullying, although no research has yet examined this possibility. Other studies have explored the effectiveness of gaming in preventing bullying (Rubin-Vaughan, Pepler, Brown, \& Craig, 2011), where one of the strengths of this approach is the individualized nature of games and the subsequent support given to students in the form of scaffolding to help them develop effective problem-solving skills, raise awareness and foster positive attitudes.

The present study adds to the existing literature by identifying three core strategies on which prevention programmes should focus to ensure that health and developmental safety measures are implemented effectively. The first of these core strategies is the development of empowerment plans supported by the use of multimodal strategies; the second is the establishment of communication spaces with students; the third concerns the development of self-regulatory skills, highlighting the value of assertiveness as one of the key components to enhance these.

\section{Method}

\subsection{Participants}

In the initial stage of the project on which the present study reports, the participants were 1355 fifth-grade pre-adolescents from both public (65.6\%) and private (34.4\%) schools, from a total population of 41 schools $(\mathrm{n}=41)$ in Bogotá, Colombia. A total of $48.4 \%$ of the pre-adolescents were male, and $51.6 \%$ were female. Most were between the ages of 9 and 11 years old $(88.7 \%$ ), and the remaining $11.3 \%$ were aged 12 years old or more. In addition to this, a high percentage (75.2\%) lived with only one of their parents. In general, most participants reported using a computer and/or another electronic device for 1 to 3 hours per day $(79.5 \%)$ and claimed to have their own cell phones $(68.1 \%)$.

\subsection{Instrument}

We applied the Revised School Violence Questionnaire (Cuestionario de Violencia Escolar Revisado, CUVE-R), adapted from Álvarez-García et al. (2011). This instrument seeks to gather data on students' perspectives regarding school violence. The social and demographic information sought included age, gender, socioeconomic stratum, and type of institution (public or private). The remainder of the questionnaire consists of 31 Likert-type items, with a scale of five answer options. Survey respondents had to indicate the extent to which acts of violence were performed by students or teachers at their institutions. The questions contemplate eight different factors: violence by teachers against students, indirect physical violence by students, direct physical violence between students, verbal violence between classmates, verbal violence by students against teachers, social exclusion, disruption in the classroom, and violence through ICTs. Results from the questionnaire produced a Cronbach's alpha of 0.924, suggesting a relatively high level of internal consistency for the questionnaire items.

\subsection{Procedures}

This mixed-method study complied with all ethical standards appropriate to the field and studies of this kind. For the purposes of this initial phase, the results concerning the quantitative phase will be reported. The questionnaire was administered between February and May 2015 in 41 educational institutions from which written consent had been obtained from both principals and parents. The study made use of purposive sampling to facilitate the identification and selection of information-rich cases for the most effective use of limited resources (Patton, 2002) and involved the identification and selection of groups of individuals that were especially knowledgeable about or experienced with the phenomenon of interest (Creswell \& Plano Clark, 2011). Of the 57 invited schools from Bogotá, Colombia, 41 were selected and included in the study, based on their availability and willingness to participate (Bernard, 2002; Spradley, 1979). The remaining 16 institutions refrained from participating, either due to conflicts in school scheduling, disconnection with the main research topic, or due to ongoing participation in studies of other kinds. From the total of 20 neighborhoods in Bogotá, we ensured 17 were represented in the present study. It was not possible to work with schools from the remaining three neighborhoods for the purposes of this study. Visits were made to all the institutions during regular school 
hours to implement the questionnaire. The neighborhoods with the greatest participatory representation in the sample were those of Suba (26\%), Ciudad Bolívar (13.5\%), and San Cristóbal (10.5\%) (see Table 1).

Table 1. Number of responses and percentage of total responses by neighborhood

\begin{tabular}{lcccc}
\hline Neighbourhood & Number & Percentage & Percentage valid & Percentage cumulative \\
\hline Antonio Nariño & 64 & 4.7 & 4.7 & 4.7 \\
Bosa & 42 & 3.1 & 3.1 & 7.8 \\
Candelaria & 1 & 0.1 & 0.1 & 7.9 \\
Chapinero & 21 & 1.5 & 1.5 & 9.4 \\
Ciudad Bolívar & 183 & 13.5 & 13.5 & 23.0 \\
Engativá & 27 & 2.0 & 2.0 & 24.9 \\
Fontibón & 76 & 5.6 & 5.6 & 30.6 \\
Kennedy & 2 & 0.1 & 0.1 & 30.7 \\
Los Mártires & 41 & 3.0 & 3.0 & 33.7 \\
Rafael Uribe Uribe & 90 & 6.6 & 6.6 & 40.4 \\
San Cristóbal & 142 & 10.5 & 10.5 & 50.8 \\
Suba & 352 & 26.0 & 26.0 & 76.8 \\
Sumapaz & 1 & 0.1 & 0.1 & 76.9 \\
Teusaquillo & 11 & 0.8 & 0.8 & 77.7 \\
Tunjuelito & 84 & 6.2 & 6.2 & 83.9 \\
Usaquén & 98 & 7.2 & 7.2 & 91.1 \\
Usme & 120 & 8.9 & 8.9 & 100.0 \\
Total & 1355 & 100.0 & 100.0 & \\
\hline
\end{tabular}

\subsection{Data analysis}

The data were processed using IBM SPSS Statistics 23 software (IBM Corporation, Armonk, NY, USA). Firstly, the frequencies for all questions - both those concerning sociodemographic data and the Likert scale items - were calculated; percentages, means (Ms), and standard deviations (SDs) for responses to each of the questions were also calculated. Secondly, this data was analyzed for relationships between violence through ICTs (cyberbullying) and traditional violence, and the Pearson's correlation between Factor 8 (violence through ICTs) and the remaining factors in the questionnaire was also calculated. Furthermore, the means and standard deviations for each factor were calculated with the goal of determining the most common types of violence.

\section{Results}

\subsection{Emergence of violence through ICTs: Cyberbullying}

According to the results from the CUVE-R questionnaire, violence through ICTs tended to present itself seldom or never - which in fact justifies the rationale for developing a cyberbullying prevention program. The type of violence through ICTs that was reported most often involved students filming peers or teachers to mock them. $8.2 \%$ of the surveyed students of students reported having witnessed this behaviour sometimes (see Table 2). 
Table 2. Percentages of responses to the questions for Factor 8 on violence through ICTs $(\mathrm{N}=1355)$

\begin{tabular}{|c|c|c|c|c|c|}
\hline Questions for Factor 8 (Violence through ICTs) & $\begin{array}{c}1 \\
\text { (Never) }\end{array}$ & $\begin{array}{c}2 \\
\text { (Seldom) }\end{array}$ & $\begin{array}{c}3 \\
\text { (Sometimes) }\end{array}$ & $\begin{array}{c}4 \\
\text { (Many } \\
\text { times) }\end{array}$ & $\begin{array}{c}5 \\
\text { (Always) }\end{array}$ \\
\hline $\begin{array}{l}\text { There are students who film or take photos of teachers with their cell } \\
\text { phones to mock them. }\end{array}$ & 82.8 & 10.6 & 3.2 & 1.7 & 1.6 \\
\hline $\begin{array}{l}\text { Some students send messages to classmates through social media } \\
\text { (Facebook. etc.) that are offensive, insulting, or threatening. }\end{array}$ & 71.8 & 16.9 & 5.6 & 2.6 & 3.1 \\
\hline $\begin{array}{l}\text { Some students film or take photos of classmates with their cell phones } \\
\text { to mock them. }\end{array}$ & 62.0 & 23.2 & 8.2 & 3.4 & 3.2 \\
\hline Students post offensive photos or videos of teachers online. & 88.2 & 7.2 & 3.0 & 0.4 & 1.2 \\
\hline Students post offensive photos or videos of their classmates online. & 78.8 & 12.7 & 4.9 & 1.9 & 1.7 \\
\hline
\end{tabular}

\subsection{Relationship between Violence through ICTs/Cyberbullying and Traditional School Violence}

The type of school violence that was most frequently reported involved disruptions in the classroom, with a mean of 2.33, followed by verbal violence between students, with a mean of 2.29. Violence through ICTs was the type of violence least frequently reported, with a mean of 1.39. The data show that the type of institution (public and/or private) did not affect the presence of violence through ICTs/cyberbullying (see Table 3).

Table 3. Means and standard deviations for student answers to the CUVE-R by factors $(\mathrm{N}=1355)$

\begin{tabular}{lcc}
\hline Factors analysed & $\mathrm{M}$ & $\mathrm{SD}$ \\
\hline Factor 1. Violence by teachers against students. & 1.58 & 0.95 \\
Factor 2. Indirect physical violence between students. & 1.67 & 0.95 \\
Factor 3. Direct physical violence between students. & 2.05 & 1.11 \\
Factor 4. Verbal violence between students. & 2.29 & 1.12 \\
Factor 5. Verbal violence by students against teachers. & 1.47 & 0.81 \\
Factor 6. Social exclusion. & 1.76 & 1.09 \\
Factor 7. Disruption in the classroom. & 2.33 & 1.12 \\
Factor 8. Violence through ICTs. & 1.39 & 0.82 \\
\hline
\end{tabular}

Table 4. Correlation of responses to questions for Factor 8 (Violence through ICTs) by type of institution $(\mathrm{N}=1355)$

\begin{tabular}{lcc}
\hline Questions for Factor 8 (Violence through ICTs) & Correlation & $\begin{array}{c}\text { Standard } \\
\text { Error }\end{array}$ \\
\hline There are students who film or take photos of teachers with their cell phones to mock them. & -0.064 & 0.024 \\
Some students send messages to classmates through social media (Facebook. etc.) that are & -0.035 & 0.026 \\
offensive, insulting, or threatening. & -0.038 \\
Some students film or take photos of classmates with their cell phones to mock them. & -0.066 \\
Students post offensive photos or videos of teachers online. & -0.045 & 0.026 \\
Students post offensive photos or videos of their classmates online. & 0.023 \\
\hline
\end{tabular}

Note. The Pearson correlations obtained for both public and private institutions were negative, as shown in Table 4.

\section{Discussion}

In terms of the frequency violence occurring through ICTs, the findings indicate that cyberbullying is only just beginning to occur in the surveyed schools. This result justifies the implementation of the project's second stage, which seeks to design and evaluate the efficacy of a cyberbullying prevention programme that contemplates the integration of ICTs and the development of communication skills. Taken together, the findings from both this study and previous studies show that it is necessary to develop prevention programmes that empower students in face of intimidation on social media and other online environments (Migliaccio \& Raskauskas, 2013), especially considering that physical and verbal violence in schools tends to translate into online violence (Foshee et al., 2014). Although decreases in school bullying generally have sometimes been reported in schools where the issue 
has been addressed directly in the classroom by teachers, most researchers strongly favor the design of prevention programs targeted specifically at cyberbullying (Couvillon \& Ilieva, 2011; Kiriakidis \& Kavoura, 2010; Williams \& Guerra, 2007). Additionally, school bullying prevention programmes that focus on effects for both the victims and perpetrators can have a variety positive effects both for the school environment and for the individual (Yaakuba, Haron, \& Leong, 2010). In any case, identifying the presence of cyberbullying and examining possible correlations between types of and factors affecting school violence are necessary steps in the kind of comprehensive needs analysis needed to help educational agents and stakeholders better comprehend their educational communities and, thereby, develop more effective cyberbullying prevention plans and long-lasting protective environments for pre-adolescents, their peers and their families.

In the present study, the percentages of students witnessing cyberbullying sometimes, many times, or always were low in comparison with comparable findings from other contexts (Álvarez-García et al., 2011). In terms of violence through ICTs and their relationship with other types of school violence, the data presented in Table 2 shows that, in the present study, the most frequently reported kind of violence was disruption in the classroom, while violence through ICTs was the least frequently reported. Given that the target population is still at a stage in which their use of ICTs is only just beginning to increase, this finding lends further support to the value of designing and implementing prevention programmes that help them learn how to use ICTs efficiently, following target protocols and standards of discretion, security and privacy, so as to protect their-and others' - personal welfare. However, we argue that pre-adolescents who find themselves (or are prone to be) in cyberbullying situations could be better prepared to face this threat by training them for a response plan that includes but is not restricted to actions such as seeking adult support (from parents, relatives, or teachers); dialoguing and reporting attacks to adults and/or governmental organizations through available contact pages and/or applications (such as http://www.teprotejo.org/index.php/es/denuncie-ciberacoso); hiding, deleting, and/or deactivating Internet/social media account features so as eliminate or reduce unsolicited/unwanted communications; being communicatively assertive; and making effective and timely decisions. Although our study suggests the implementation of these strategies, further research is needed to determine their effectiveness, pinpointing the most efficient ways of providing training in such prevention and response plans. We hold the belief that pre-adolescents must first both gain understanding and awareness of what cyberbullying entails as well as be trained in doable ways to face the risks. Early prevention programs focused on the development of target communication (focused on the development of assertiveness) and self-regulatory skills could prove beneficial to enhance gradual empowerment to face the phenomenon.

A way to start gauging the development of assertive communication mechanisms needed to help pre-adolescents to regulate their emotions and recognize potential opportunities and risks would be by focusing on the differences between communication styles: passive, aggressive, passive aggressive, and assertive. Pre-adolescents need to be cognizant of the distinctions between the types and actions characterising those styles to be able to understand that the first three risk the safe expression of feelings, the protection of individual rights, and individual tolerance - aspects that ultimately interfere with positive and functional interpersonal relationships. Additionally, prevention programs should examine ways to develop skills such as self-efficacy and self-confidence, which can assist pre-adolescents in establishing safe, sensitive, protective environments and supportive relationships, as well as in enhancing their management of conflict-resolution as might be called for in the event of a cyberbullying attack. Based on the results of this study, possible targets for prevention and early intervention should be oriented towards the training of students to manage conflict and to foster self-efficacy skills in the facing of cyberbullying. The more they believe they can front these threats, the more assertive and resourceful they could be in finding effective response strategies to resist to victimization and perpetration situations. Through sensitization, awareness-raising (Barkoukis, Lazuras, Ourda, \& Tsorbatzoudis, 2016), exemplification, and constant monitoring and assessment of authentic cyberbullying cases (Hemphill \& Heerde, 2014) (both at home and school environments) learners could be gradually empowered to manage and face the risks and to take stands when necessary.

\section{Conclusion}

Based on the results of the present study, we propose three recommendations for designing and implementing cyberbullying prevention programmes to support the development of appropriate communication skills and uses of social media. Firstly, prevention programs to be included in curriculum design should make use of empowerment plans and interventions that contain self- peer-, and group-assessment activities, as well as multimodal strategies and ICT tools with emphases on security, privacy and identity issues including (but not necessarily restricted to) classroom videos and discussion groups, online discussion forums, role-plays, and online social media simulators, such as Edmodo (a free social learning network that facilitates teachers and 
students' communication, interaction and the sharing of resources). The usage of such resources would allow more realistic practice of ICT skills in controlled environments.

Secondly, it is important to create spaces for communication with students as a method of preventing acts of violence that could result at least partially from a lack of spaces for students to express themselves and to be recognized by their social groups. Thus, classrooms should be viewed as scenarios in which students are trained to develop empathy (Ang, 2015) and assessed to develop and boost their self-recognition, resiliency, emotional regulation, repair, and group cohesion skills so that they feel valued for their thoughts and behaviours. Being better equipped in these respects would help them be better able to face cyberbullying assertively, but without resorting to acts of violence of their own to acquire a group identity.

Thirdly, students need to learn that self-regulation is also mediated by the action of group influences and to understand that social and individual processes occur concurrently though the representation of different systemic levels (Volet et al., 2009). Thus, in examining co-regulatory factors and conditions that enable individuals to control their learning and contribute to their group's ability to control theirs, learners also gain expertise in controlling their actions. Hence, educators and researchers should focus on the analysis of discourse practices co-constructed by the community's participants (Nolen \& Ward, 2008) when scrutinizing what lies behind individual reflection and action levels. All in all, the more skills students acquire to be emotionally assertive and self-regulated, the more empowered they will feel as they continue to develop their social interaction skills, using technology to support their daily lives - and not the other way around.

Limitations on the study included bureaucratic restrictions on working with some schools, as their directing boards only permitted them to enroll in projects that were sponsored/cofounded by governmental bodies, specifically the Ministries and Secretariats of Education and/or (especially in the case of private schools) local and national school-board associations. Our team of researchers invested large quantities of time in contacting, visiting, and persuading school representatives of the benefits of the project and the importance of gauging prevention programs in their schools in response to the cyberbullying phenomenon. In future studies of this kind, the researchers suggest establishing contact with these entities in early phases to mitigate such difficulties.

\section{Acknowledgments}

The authors acknowledge the support given to this project (identified with the code CTA-20-2015) by the financing institution, the involved academic units and the Direction of Research.

\section{References}

Aboujaoude, E., Savage, M. W., Starcevic, V., \& Salame, W. O. (2015). Cyberbullying: Review of an old problem gone viral. Journal of Adolescent Health. https://doi.org/10.1016/j.jadohealth.2015.04.011

Álvarez-García, D., Núñez, J. C., Álvarez, L., Dobarro, A., Rodríguez, C., \& González-Castro, P. (2011). Violencia a través de las tecnologías de la información y la comunicación en estudiantes de secundaria. Anales de Psicología, 27(1), 221-231.

Barkoukis, V., Lazuras, L., Ourda, D., \& Tsorbatzoudis, H. (2016). Tackling psychosocial risk factors for adolescent cyberbullying: Evidence from a school-based intervention. Aggressive Behavior, 42(2), 114-122. https://doi.org/10.1002/ab.21625

Bazelon, E. (2013). Sticks and stones: Defeating the culture of bullying and rediscovering the power of character and empathy. New York: Random House.

Bender, D., \& Lösel, F. (2011). Bullying at school as a predictor of delinquency, violence and other anti-social behaviour in adulthood. Criminal Behaviour and Mental Health, 21(2), 99-106. https://doi.org/10.1002/cbm.799

Bernard, H. R. (2002). Research methods in anthropology: Qualitative and quantitative approaches. Walnut Creek, CA: Altamira Press.

Cabra, F., \& Marciales, G. (2015). Cyberbullying and education: A review of emergent issues in Latin America research. In R. Navarro, S. Yubero, \& E. Larrañaga (Eds.), Cyberbullying across the globe: Gender, family, and mental health (pp. 131-147). Cham, Switzerland: Springer International. https://doi.org/10.1007/978-3-319-25552-1_7

Connolly, J., Pepler, D., Craig, W., \& Taradash, A. (2000). Dating experiences of bullies in early adolescence. Child Maltreat, 5(4), 299-310. https://doi.org/10.1177/1077559500005004002

Couvillon, M. A., \& Ilieva, V. (2011). Recommended practices: A review of schoolwide preventative programs 
and strategies on cyberbullying. Preventing school failure: Alternative education for children and youth, 55(2), 96-101. https://doi.org/10.1080/1045988X.2011.539461

Creswell, J. W., \& Plano Clark, V. L. (2011). Designing and conducting mixed-methods research. The Sage handbook of qualitative research (2nd ed.). Thousand Oaks, CA: Sage.

Evans, C. B. R., Fraser, M. W., \& Cotter, K. L. (2014). The effectiveness of school-based bullying prevention programs: A systematic review. Aggression and Violent Behavior, 19(5), 532-544. https://doi.org/10.1016/j.avb.2014.07.004

Fernández, I., \& Cuadrado, I. (2014). Predictive indicators of victimization and aggression in cyber contexts. American International Journal of Social Science, 3(6), 15-23.

Foshee, V. A., McNaughton Reyes, H. L., Vivolo-Kantor, A. M., Basile, K. C., Chang, L. Y., Faris, R., \& Ennett, S. T. (2014). Bullying as a longitudinal predictor of adolescent dating violence. Journal of Adolescent Health, 55(3), 439-444. https://doi.org/10.1016/j.jadohealth.2014.03.004

Frison, E., \& Eggermont, S. (2016). "Harder, better, faster, stronger": Negative comparison on Facebook and adolescents' life satisfaction are reciprocally related. Cyberpsychology, Behavior, and Social Networking, 19(3), 158-164. https://doi.org/10.1089/cyber.2015.0296

Fullwood, C., James, B. M., \& Chen-Wilson, C.-H. (2016). Self-concept clarity and online self-presentation in adolescents. Cyberpsychology, Behavior, and Social Networking, 19(12), 716-720. https://doi.org/10.1089/cyber.2015.0623

Garaigordobil, M. (2017). Conducta antisocial: Conexión con bullying/cyberbullying y estrategias de resolución de conflictos. Psychosocial Intervention, 26(1), 47-54. https://doi.org/10.1016/j.psi.2015.12.002

Hemphill, S. A., \& Heerde, J. A. (2014). Adolescent predictors of young adult cyberbullying perpetration and victimization among Australian youth. Journal of Adolescent Health, 55(4), 580-587. https://doi.org/10.1016/j.jadohealth.2014.04.014

Hennig, C., Cuesta-Medina, L., \& Malfasi, S. (2017). Prevention of school bullying and cyberbullying in the scientific literature. Manuscript submitted for publication.

Hinduja, S., \& Patchin, J. W. (2010). Bullying, Cyberbullying, and Suicide. Archives of Suicide Research, 14(3), 206-221. https://doi.org/10.1080/13811118.2010.494133

Kiriakidis, S. P., \& Kavoura, A. (2010). Cyberbullying: A review of the literature on harassment through the internet and other electronic means. Family Community Health, 33, 82-93.

Kowalski, R. M., \& Limber, S. P. (2013). Psychological, physical, and academic correlates of cyberbullying and traditional bullying. Journal of Adolescent Health, 53(1), S13-S20. https://doi.org/10.1016/j.jadohealth.2012.09.018

Migliaccio, T., \& Raskauskas, J. (2013). Small-scale bullying prevention discussion video for classrooms: A preliminary evaluation. Children and Schools, 35(2), 71-81. https://doi.org/10.1093/cs/cdt003

Monks, C. P., Robinson, S., \& Worlidge, P. (2012). The emergence of cyberbullying: A survey of primary school pupils' perceptions and experiences. School Psychology International, 33(5), 477-491. https://doi.org/10.1177/0143034312445242

Nolen, S. B., \& Ward, C. J. (2008). Sociocultural and situative approaches to studying motivation. In M. L. Maehr, S. A. Karabenick, \& T. C. Urdan (Eds.), Social psychological perspectives (pp. 425-460). Bingley: Emerald. https://doi.org/10.1016/S0749-7423(08)

Palladino, B. E., Nocentini, A., \& Menesini, E. (2012). Online and offline peer led models against bullying and cyberbullying. Psicothema, 24(4), 634-639.

Patton, M. (2002). Qualitative evaluation and research methods (3rd ed.). Thousand Oaks, CA: Sage.

Rincón, R. A. I., \& Ávila, D. W. D. (2014). Simbiosis vital para describir el ciberbullying en Colombia. Revista Científica General José María Córdova, 12(14), 149-164.

Rubin-Vaughan, A., Pepler, D., Brown, S., \& Craig, W. (2011). Quest for the Golden Rule: An effective social skills promotion and bullying prevention program. Computers and Education, 56(1), 166-175. https://doi.org/10.1016/j.compedu.2010.08.009

Sampasa-Kanyinga, H., Roumeliotis, P., Farrow, C. V., \& Shi, Y. F. (2014). Breakfast skipping is associated with cyberbullying and school bullying victimization. A school-based cross-sectional study. Appetite, 79, 76-82. 
https://doi.org/10.1016/j.appet.2014.04.007

Schneider, S. K., O’Donnell, L., Stueve, A., \& Coulter, R. W. S. (2012). Cyberbullying, school bullying, and psychological distress: A regional census of high school students. American Journal of Public Health, 102(1), 171-177. https://doi.org/10.2105/AJPH.2011.300308

Slonje, R., Smith, P. K., \& Frisén, A. (2013). Computers in human behavior the nature of cyberbullying, and strategies for prevention. Computers in Human Behavior, 29(1), 26-32. https://doi.org/10.1016/j.chb.2012.05.024

Sourander, A., Brunstein Klomek, A., Ikonen, M., Lindroos, J., Luntamo, T., Koskelainen, M., Ristkari, T., \& Helenius, H. (2010). Psychosocial risk factors associated with cyberbullying among adolescents. Archives of General Psychiatry, 67(7), 720. https://doi.org/10.1001/archgenpsychiatry.2010.79

Spies Shapiro, L. A., \& Margolin, G. (2014). Growing up wired: Social networking sites and adolescent psychosocial development. Clinical Child and Family Psychology Review. https://doi.org/10.1007/s10567-013-0135-1

Spradley, J. P. (1979). The ethnographic interview. New York, NY: Holt, Rinehart \& Winston.

Swearer, S. M., Espelage, D. L., Vaillancourt, T., \& Hymel, S. (2010). What can be done about school bullying? Linking research to educational practice. Educational Researcher, 39(1), 38-47. https://doi.org/10.3102/0013189X09357622

Ttofi, M. M., \& Farrington, D. P. (2012). Risk and protective factors, longitudinal research, and bullying prevention. New Directions for Youth Development, (133), 85-98. https://doi.org/10.1002/yd.20009

von Marees, N., \& Petermann, F. (2012). Cyberbullying: An increasing challenge for schools. School Psychology International, 33(5), 467-476. https://doi.org/10.1177/0143034312445241

Williams, K. R., \& Guerra, N. G. (2007). Prevalence and predictors of Internet bullying. Journal of Adolescent Health, 41(6), S14--S21. https://doi.org/10.1016/j.jadohealth.2007.08.018

Yaakuba, N. F., Haron, F., \& Leong, G. C. (2010). Examining the efficacy of the Olweus prevention programme in reducing bullying: The Malaysian experience. Procedia - Social and Behavioral Sciences, 5, 595-598. https://doi.org/10.1016/j.sbspro.2010.07.148

Zimmer-Gembeck, M. J., Waters, A. M., \& Kindermann, T. (2010). A social relations analysis of liking for and by peers: Associations with gender, depression, peer perception, and worry. Journal of Adolescence, 33(1), 69-81. https://doi.org/10.1016/j.adolescence.2009.05.005

\section{Copyrights}

Copyright for this article is retained by the author(s), with first publication rights granted to the journal.

This is an open-access article distributed under the terms and conditions of the Creative Commons Attribution license (http://creativecommons.org/licenses/by/4.0/). 